\title{
Allan Boesak, Black Theology and Apartheid: A theological-historical approach
}

\author{
Eugene Fortein \\ Stellenbosch University, South Africa \\ dseugenef@gmail.com
}

\begin{abstract}
In this article I will give specific attention to the reciprocal relationship between Black Theology and Allan Boesak based on his lived experience of apartheid from a theological-historical perspective. It is my presupposition that Boesak's experience of apartheid made him prone to the influence of Black Theology and that he in turn adapted American Black Theology so that it could be made applicable to the South African context. Black Theology unlocked an entire new theological paradigm for Boesak which enabled him to speak prophetically to the challenges and injustices that occurred under apartheid in South Africa. Attention will be given to the emergence of Black Theology in South Africa, how Boesak was challenged by it and how Black Theology, through Boesak, impacted the theological landscape.
\end{abstract}

\section{Key words}

Boesak; Black Theology; apartheid; Biko; Black Consciousness

\section{Introduction}

When one attempts to reflect on the possible influence of Black Theology on Allan Boesak, one needs to come to terms with how Boesak experienced the injustices of apartheid and how that impacted on him. Boesak's entire life's experience of apartheid made him susceptible to the various principles of Black Theology as I will attempt to prove. In this instance Boesak's early childhood can serve as a definite point of departure. Allan Boesak was born in Kakamas to Willie and Sarah Boesak. ${ }^{1}$ Boesak's father died when he was 7 years old, after which after the family moved to Somerset West in

1 Scholtz, A. 1988. Die verhaal van Allan Boesak, published doctoral dissertation, 1. 
search of employment for Boesak's mother. It was a very challenging time for the family, seeing that Boesak's mother now must provide for him and his brothers and sister. Amidst the challenges the family faced, religion was always an integral part of their family life. The reading of the Bible, prayers and discussions on Bible stories contributed that the family came to know God in a special way. ${ }^{2}$ The Bible always served as a source of comfort and inspiration for the family.

And when you are really poor, then the Biblical story is not just another story. When it is applied to your life, often in a very powerful way that it was in our lives, it becomes very meaningful; in fact, one of the very few meaningful things in your life. ${ }^{3}$

As a child Boesak remembers how everyone wanted to be white or wanted to be accepted by whites. White was the benchmark of being a human being. The darker your skin tone, the less human you are:

When I was a child everybody wanted to be accepted by whites.

Other children were not allowed to play with us because we were too dark-skinned. And I remember my mother, who was very fair, being approached and told that if she would give us out for adoption it could be arranged for her to be reclassified as white. ${ }^{4}$

Boesak's mother was one of his most influential spiritual educators. He learned from his mother that God in a special way cares for the widow and the fatherless. ${ }^{5}$ Whenever Boesak states that God is the God of the poor, of the widow and the fatherless and that God calls one to stand where $\mathrm{He}$ stands, is not only a conviction to which Boesak came know through Black Theology. It was a first-hand lesson he learned from his mother. ${ }^{6}$

2 Wallis, T. 1989. "At the Apocalypse: The South African Church Claims Its Hope. An interview with Allan Boesak", in: J. Wallis \& J. Holiday (reds.), Crucible of Fire. The Church confronts Apartheid (Maryknoll: Orbis Books), 41.

3 J. Wallis \& J. Holiday (reds.), Crucible of Fire, 41.

4 Sparks, A. 2003. The Mind of South Africa. The Story of the Rise and Fall of Apartheid. Jeppestown: Jonathan Ball Publishers (PTY) Ltd, 73.

5 J. Wallis \& J. Holiday (reds.), Crucible of Fire, 42.

6 J. Wallis \& J. Holiday (reds.), Crucible of Fire, 43. 


\section{The challenge to be a prophet}

Boesak was ordained in 1968 in the then Dutch Reformed Mission Church in Paarl at the age of 23. ${ }^{7}$ It was during his ministry in Paarl where Boesak became more aware of the unjust laws of the apartheid regime. Even during his years of theological training Boesak became aware that the theological training he was receiving from the white missionaries was inadequate to equip him to address the challenges of the day. ${ }^{8}$ Boesak went into the ministry with this void in his theological armour and this void emerged in a profound way in the events with one of Boesak's congregants, Tant Meraai Arendse.

Paarl was one of the towns that were heavily struck by the Group Areas Act. ${ }^{9}$ It was during the ministry of Boesak in Paarl that an area where the church building was situated was declared a white area under the Group Areas Act. ${ }^{10}$ A multitude of so called coloured families were uprooted and had to move to weaker economical and under developed areas. Communities were shattered apart and the spirit of belonging and companionship extinguished. Boesak's congregation was in the middle of all of this and it forced him to reflect on the situation. One of these congregants was Tant Meraai Arendse. ${ }^{11}$ As Tant Meraai and Boesak were looking on as her house was being demolished, she asked him, what is God saying about these injustices? Why is God allowing this to happen? She said that she will be in church the following Sunday and that she wants to hear what God has to say about this. ${ }^{12}$ That was the point that Boesak came to the conclusion that at no point during his five-year theological training was he prepared for a challenge such as this.

7 Boesak, A.A. 2009. Running With Horses. Reflections of an accidental politician. Cape Town: Joho Publishers, 33.

8 J. Wallis \& J. Holiday (reds.), Crucible of Fire, 44.

9 According to this act, urban areas were to be divided into racially segregated zones where members of one specific race alone could live and work. Group areas were created for the exclusive ownership and occupation of a designated group. It further became a criminal offence for a member of one racial group to reside on or own land in an area set aside by proclamation for another race.

10 Scholtz, Die verhaal van Allan Boesak, 2.

11 Boesak, Running With Horses, 33.

12 Boesak, Running With Horses, 34. 
The theology taught to me by the white Dutch Reformed missionaries was totally inadequate to deal with the crises of faith that grew out of poverty, socio-economic injustices and political oppression. For this devastation we had no words in our creeds, doctrines and theology; or in the Bible. Or so they made us believe. ${ }^{13}$

This was a life changing event for Boesak. This event will set him on a course to fill that theological void to a point that he can speak to the South African situation. This search will lead Boesak to the Netherlands where he will do research for his doctoral dissertation.

Boesak returned to South Africa in 1976 after he obtained his doctorate in Black Theology and Black Power entitled, Farewell to Innocence. A SocialEthical Study on Black Theology and Black Power. Black Theology, according to Boesak, knows that it is not merely people that need to be liberated. The gospel, often so abused and exploited, also needs to be liberated and it is in this movement that black Christians engage themselves. Having said this, an important aspect in liberating both people and the gospel is how one understands theology.

\section{Black Theology and the black experience}

Within his study it becomes evident how the Black experience in South Africa plays in on Boesak's analysis of the American and South American Black Theologians James Cone and Gustavo Gutiérrez. Boesak will later utilize both Cone and Gutiérrez to great effect in formulating his anti-apartheid arguments. Various sermons, speeches and theological declarations like that of the "Belydende kring" and ABRECSA is indicative of how Boesak modified the message of various American Black Theologians to speak to the Black experience in South Africa.

In his analysis of Black Theology Boesak makes a distinction on how James Cone and Gustavo Gutiérrez describe theology respectively. This distinction is crucial when you attempt to interpret the gospel of Jesus Christ during the Black experience. Cone sees theology as the "rational study of the being of God in the light of the existential situation of the

13 Boesak, Running With Horses, 34. 
oppressed community, relating to the essence of the gospel, which is Jesus Christ. ${ }^{14}$ Gutiérrez on the other hand view the Word of God as "incarnated in the community of faith, which gives itself to the service of humankind". ${ }^{15}$ This activity of the church as the community of faith must be the starting point of all theological reflection.

Gutiérrez places new emphasis on praxis that is set to transform the community by means of a Christian life centred on an absolute commitment of service to others. Boesak shares the view of Gutiérrez that theology which is the reflection upon action on transforming the world, is nothing else than active faith. For Gutiérrez and Boesak faith is not just a mere confession, but rather as an act of trust in and commitment to God and to humanity. ${ }^{16}$ Boesak describes his understanding of theology as follows:

Is the Christian faith the acceptance of the correct interpretation of certain texts, or is the Christian faith the commitment to obedience to the Lord Jesus Christ? If it is the latter, really, the question is, how this obedience expresses itself concretely, so that you really know how the text has to be understood in relation to your total Christian experience. So actually you cannot say whether you read the text correctly until you say how you treat the poor farmer. This, I would say, is theology. So that really the correct interpretation of the text has to tell me how you have dealt with the poor farmer and therefore with the rich landowner who owns his work. ${ }^{17}$

According to Boesak theology cannot merely be perceived as a psychological, spiritual or a philosophical process. Theology cannot be detached or neutral. ${ }^{18}$ Theology is passionately involved in the actual struggles and suffering within a given situation and community. Thus for black people this means that theology must engage itself in the black experience. Boesak believes God reveals himself in the situation. The black experience thus

14 Boesak, A.A. 1976. Farewell to Innocence. A Social-Ethical Study on Black Theology and Black Power. Kampen: Uitgeversmaatschapij J. H. Kok, 15.

15 Boesak, Farewell to Innocence, 15.

16 Boesak, Farewell to Innocence, 16.

17 Boesak, Farewell to Innocence, 14.

18 Boesak, Farewell to Innocence, 16. 
provides the framework within which blacks understand the revelation of God in Jesus Christ. ${ }^{19}$

For the adherents of Black Theology, theology is a living experience. Boesak states that a theology of liberation is not just a logos about the Theos. ${ }^{20}$ This theology proclaims the Word, which always has been a liberating action. This theology wants to participate in the liberating activities of the God who reveals Himself in the person of Jesus Christ. Boesak asserts the fact that Black Theology can rightly be seen as an Christological theology, i.e. that Christ is at the heart of this theology. ${ }^{21}$

It means that the passion moving black theologians is essentially Passio Jesu Christi. Thus, theology becomes a liberating activity with an openness to the world and to the future, a prophetic word, but also a prophetic manifestation of the Word. ${ }^{22}$

Having stated the above, Black Theology can be described as a situational theology. Black Theology is the attempt of black people to come to terms theologically with their black situation. It seeks to interpret the gospel of Jesus Christ in such a way that the situation that black people find themselves in, make sense. It seeks to transform the departmentalized theology that blacks inherited from the western world into a Biblical, holistic theology. ${ }^{23}$

Boesak also refers to Black Theology as contextual theology. ${ }^{24}$ Authentic Black Theology is a prophetic theology. It takes the good from the past, looks critical at the present and creates new perspectives for the future. Boesak states that this is a process that is always arising out of the genuine encounter between God and His world. This theology always seeks to convey the central message of the gospel in any given situation, i.e. liberation.

Black Theology is a theology of black liberation. It seeks to plumb the black condition in the light of God's revelation in Jesus Christ,

19 Boesak, Farewell to Innocence, 16.

20 Boesak, Farewell to Innocence, 16.

21 Boesak, Farewell to Innocence, 17.

22 Boesak, Farewell to Innocence, 17.

23 Boesak, Farewell to Innocence, 17.

24 Boesak, Farewell to Innocence, 18. 
so that the black community can see that the gospel is commensurate with the achievement of black humanity. Black Theology is a theology of 'blackness'. It is the affirmation of black humanity that emancipates black people from white racism, thus providing authentic freedom for both white and black people. It affirms the humanity of white people in that it says 'No' to the encroachment of white oppression. ${ }^{25}$

In her book The voice of Black Theology in South Africa, Louise Kretzchmar states that Black Theology in South Africa offers a unique dimension in terms of the interpretation the black context. ${ }^{26}$ She also states that the South African Black Theology possesses the remarkable ability to unmask the hidden prejudices of the white theology. Black Theology opens the gospel for blacks in their context in profound way. Boesak was at the forefront of opening the gospel in Black experience of apartheid South Africa, unmasking the lies and deceit of the white Dutch Reformed Theology. Boesak was one of the major role players of combining the American Black Theologians like Martin Luther King Jr etc. and reinterpreting their message to liberate the masses in South Africa. The same gospel that was used to declare blacks as unworthy was now reinterpreted to add dignity to blacks.

The banning of the liberation movements in the late 1960's and early 1970's left a lacuna among blacks in the struggle for liberation. This lacuna was filled by a young and new leadership that was military driven. This generation envisaged a new vision. Boesak states that this vision was interwoven with an urgency and inclusivity that was unknown to the older generation. ${ }^{27}$ The phrase of "black power" started to emerge. These new dynamics in the liberation struggle understood the importance of transnational black solidarity. It was this reality that found a new phrase among the youth of South Africa, i.e. black consciousness. ${ }^{28}$

25 Boesak, Farewell to Innocence, 18.

26 Kretzchmar, L. 1986. The Voice of Black Theology in South Africa. Johannesburg: Ravan Press, 73.

27 Boesak, A.A. 2005b. The Tenderness of Conscience. African Renaissance and the Spirituality of Politics. Stellenbosch: SUN Press, 8.

28 Boesak, The Tenderness of Conscience, 8. 
It set in motion an unprecedented wave of resistance after a long vacuum in the politics of resistance in South Africa that would not stop until the white minority regime finally had to give in to pressure. $^{29}$

Boesak was part of a generation that was born and raised in a racial divided society where every sphere of life was organized according to the pigmentation of one's skin. Signs saying "whites only" and "non-Europeans only" were visible everywhere in society. Separate neighbourhoods, schools, beaches etc. was the way of life in apartheid South Africa. Boesak was also part of the generation who experienced the unifying bond that black power brought about. Bound together by the struggle for justice, Boesak's generation rallied together to fight for their freedom. He saw how the situation of oppression unified blacks to create a strong resistance against the racial system of apartheid. This all played in Boesak's decision to study the field of Black Theology in the Netherlands.

\section{Biko, Boesak and Black Theology}

Steve Biko and the philosophy of Black Consciousness was another major role player that shaped and challenged Boesak and other black church leaders to preach the gospel in such a way that Black people in South Africa would come to embrace their blackness as a God-given gift. Up to this point the gospel was used to justify segregation and white supremacy. How can the same gospel be utilized to answer Biko's challenge? Boesak took it upon himself to answer Biko's call.

Biko regularly published in a column in SASO's (South African Student's Organization) newspaper entitled "I write what I like" under the pseudonym "Frank Talk". ${ }^{30}$ The crux of his column was that black people first need to be liberated of their feeling of inferiority and their subsequent glorifying of white values, before they can be liberated politically. Biko writes in one of his columns:

29 Boesak, The Tenderness of Conscience, 8.

30 Stubbs, A (ed). 2004. Steve Biko: I Write What I Like - A Selection of His Writings. Johannesburg: Picador Africa. 1. 
This is the truth, bitter as it may seem, that we have to acknowledge before we can start on any program designed to change the status quo. It becomes more necessary to see the truth as it is if you realise that the only vehicle for change are these people who have lost their personality. The first step therefore is to make the black man come to himself; to pump back life into his empty shell; to infuse him with pride and dignity, to remind him of his complicity in the crime of allowing himself to be misused and therefore letting evil reign supreme in the country of his birth. This is what we mean by an inward-looking process. This is the definition of "Black Consciousness". ${ }^{31}$

Through utilizing legislation in minute detail, the apartheid government amputated any possible avenues where blacks could articulate their frustration. Some blacks were forced to join the government-created programmes, like the homelands. Others did not see any advantage in participating in the government programs. In his book The Rise and Fall of Apartheid, David Welsch describes how the apartheid legislation was used over time to rob blacks of their dignity. Welsch states that the heartbeat of the illusion of apartheid was the idea that each population group has the best opportunity to develop socially and economically, given the fact that this development occurs within a closed ethnic group with as minimal contact with other ethnic groups as possible. ${ }^{32}$ The Native Land Act, Pass Laws, Population Act was just some of the laws used to regulate the life and movement of blacks. It was important for Biko that blacks were to be liberated from this oppressive legislation.

Biko saw the liberation of black people on two levels, i.e. psychological and physical liberation. For Biko and the black consciousness movement the reference to "black" was not just a reference to black people in particular, but rather a reference to "coloureds" and Indians and other people who suffer under any form of oppression. ${ }^{33}$ It was important for Biko that black

31 Stubbs, Steve Biko: I write what I like, 29.

32 Welsh, D.2009. The Rise and Fall of Apartheid. Johannesburg and Cape Town: Jonathan Ball Publishers, 212.

33 The term "coloured" was given to people of colour or mixed decent by the apartheid government. 
citizens should rediscover their human dignity and their proudness to be black in the midst of fierce oppression. For Biko the oppression of black people went on for far too long and the time has come for black people to rise up against their oppressors and claim back their rightful place in society. Boesak describes black consciousness as the awareness of blacks that their humanity is encapsulated by their blackness. ${ }^{34}$ Hence black people will longer have to shy away from their blackness and that they can now acknowledge and embrace their black history and culture, one that is different from that of whites.

It means that black people are determined to be judged no longer by, and to adhere themselves no longer to white values. It is an attitude, a way of life. ${ }^{35}$

The intensity of the black consciousness movement must be viewed and understood against the backdrop of centuries of intellectual and cultural dominance and indoctrination. The movement came as a unifying factor among the oppressed people of South Africa. There was solidarity that stretched across ethnic, cultural and racial boundaries. For Boesak the philosophy of the black consciousness movement was the most liberating experience for the young generation of that time. ${ }^{36}$ The movement brought about a fundamental paradigm shift in that generation's thoughts and political actions. Black consciousness served as the vehicle by which the oppressed black people embraced their diversity as a source of inspiration. This gave the oppressed the courage to be black. ${ }^{37}$

According to Boesak the black consciousness movement was essentially the first non-racial experience they ever experienced. ${ }^{38}$ This was a very important element of the liberation struggle during the 1980's. Genuine non-racialism can only become a reality where people are equal. Without the affirmation of the dignity of black people non-racialism will only remain a meaningless theory.

34 Boesak, Farewell to Innocence, 9.

35 Boesak, Farewell to Innocence, 9.

36 Boesak, Farewell to Innocence, 9.

37 Boesak, Farewell to Innocence, 9.

38 Boesak, Farewell to Innocence, 9. 
Black Consciousness understood that the affirmation of black human dignity had personal, psychological, theological and political consequences. The new-found pride in their cognizance of "the deliberateness of God's plan in creating black people black", to continue Biko's argument, meant that "liberation, therefore, is of paramount importance in the concept of Black Consciousness". ${ }^{39}$

Black Consciousness provided the much-needed impetus for the new phase in the liberation struggle at a time when the liberation struggle became stagnant due to the irreconcilable attitude of the white nationalist government and the lack of leadership due to oppression, imprisonment and expulsion among blacks. The philosophy behind Black Consciousness reminded blacks that the acknowledgement of their blackness are an essential element their humanity. Boesak also asserts that, in relation to Black Theology, to be black is a crucial factor in understanding Jesus Christ as Lord. ${ }^{40}$

\section{Blackness - disgrace or pride?}

Within the context of apartheid South Africa black people's blackness was used to degrade them to second class citizen. It determined your entire way of life. As Boesak puts it,

It determines his whole life, every single day. It means living in constant fear, always being dehumanized and humiliated; at the mercy of people who for three hundred years have shown in so many ways that they do not know the meaning of the word. ${ }^{41}$

Blackness was consequently seen as something that blacks needed to be ashamed about - or so whites wanted blacks to believe. Emanating from his childhood experiences, theological studies and his time in ministry in the congregation of Paarl, Boesak already knew that the traditional Christian theology was never sufficient to even scratch on the surface of the situation that blacks find themselves in. Boesak's encounter with the fundamentals of

39 Boesak, Farewell to Innocence, 9.

40 Boesak, Farewell to Innocence, 26.

41 Boesak, Farewell to Innocence, 26. 
Black Theology enabled him to assess the situation and address the pressing issues of discrimination and injustices from a theological framework. This also enabled Boesak to formulate both a theology of prophetic resistance and later on, what I call, a politics of resistance or refusal.

For Biko, Boesak and the rest of the Black Consciousness movement it was important that their blackness were to be acknowledged and that whites should accept blacks as black people. This gave black people a renewed urge to awake from a mentality of contentment and acquiescence to fully embrace their blackness. With this rise in black consciousness blacks began to affirm their blackness. Slogans like "Black is Beautiful" and "Black man, you are on your own" became increasingly heard. Boesak is of the view that for people to become authentically black is a similar experience to a rebirth. ${ }^{42}$ This rebirth of blackness is a consciousness, an attitude. Boesak describes this attitude is a bold and serious determination to be a person in one's own right. ${ }^{43}$

Blackness is therefore much more than the mere pigmentation of a person's skin. Within the framework of Black Theology and Black Consciousness blackness refers to solidarity in suffering and oppression of the descendants of those who suffered under slavery and colonialism. It is within this context that Black Theology speaks of the necessity of self-love. ${ }^{44}$ Boesak emphasizes the fact that this love is not a love for black and a hate against white. Jesus did not prescribe a law when He said to love your neighbour. According to Boesak Jesus only stated the acceptance of normal fact of life. Black Theology goes out from the presupposition that self-love can only be understood within the context that Jesus intended it, i.e. the context of the love for the other. ${ }^{45}$ Basil Moore thinks along the same avenue when he asserts that Black Theology does not ask for blacks to hate whites, but rather to rediscover and affirm their identity. ${ }^{46}$

In this regard Biko states:

42 Boesak, Farewell to Innocence, 26.

43 Boesak, Farewell to Innocence, 27.

44 Boesak, Farewell to Innocence, 27.

45 Boesak, Farewell to Innocence, 27.

46 Moore, B (ed). 1973. Black Theology. The South African Voice. London: C. Hurst \& Company, 63. 
The Bible must not be seen to preach that all authority is divinely instituted. It must rather preach that it is a sin to allow oneself to be oppressed. The Bible must continually be shown to have something to say to the black man to keep him going in his long journey towards realisation of the self. This is the message implicit in 'black theology'. Black Theology seeks to do away with the spiritual poverty of the black people. ${ }^{47}$

Boesak maintains the position that people can learn to hate themselves if their dignity is undermined over a long period of time. He states that if abnormal circumstances persist long enough it can become an acceptable and normal way of life for people. ${ }^{48}$ When this happens all other possible and meaningful relationships with others are being shelved.

In such a situation, it is necessary to repeat the words of Jesus not merely as an affirmation, but as a divine demand. ${ }^{49}$

This was the situation where blacks found themselves in. Slavery, domination, injustice, being forced to live a life of contradiction and alienation within the country of their birth, all contributed to break down the sense of self dignity under blacks. Boesak states that a wound that has scared the soul does not heal easily. ${ }^{50}$ It is along the avenues of Black Theology and Black Consciousness, away from the white theology, that blacks seek to search for their own dignity. In the light of Black Theology self-love does not refer to a hate of whites. It rather means that blacks will no longer tolerate a brotherhood where the one brother is the "baas" other. Black Theology promotes the idea that white values will no longer be seen as the benchmark.

47 Stubbs. Steve Biko: I write what I like, 31.

48 Boesak, Farewell to Innocence, 28.

49 Boesak, Farewell to Innocence, 28.

50 Boesak, Farewell to Innocence, 28.

51 This is an Afrikaans word which means "baas" if translated. This was the common form by which blacks were taught to address white males. The boss's son was referred to as "kleinbaas", which means "litte or small boss". This form of address immediately set the tone regarding who is the superior in this relationship. 
Boesak came to conclusion that for blacks to love themselves, they first need to learn to hate oppression and slavery. ${ }^{52}$ Blacks will have to rediscover their God given value and also start to believe in that value. This emphasizes the fact this renaissance in this search of the self-love for blacks is not a hate towards whites, but rather a hate towards oppression: "And hate they must. With all their heart". ${ }^{53}$ It is clear from a Black Theological perspective that as long as whites are the oppressors they never can become a brother or sister. This was one of the major driving forces behind the work and life of Allan Boesak, to work for a non-racial and undivided society.

\section{Conclusion}

Kretzchmar asserts that there are factors playing in when interpreting the Bible. She states that factors like education and the church context plays a major role when interpreting the Bible. ${ }^{54}$ This was certainly the case with Boesak with regards to Black Theology and apartheid. In this article I attempted to prove how Boesak's lived experience of apartheid along with his exposure to Black Theology played in his understanding of God and His creation. It was further proofed how American Black Theology influenced the thoughts of Allan Boesak and how he adapted American Black Theology to address the injustices of apartheid South Africa. Boesak utilized the hermeneutical keys of context and liberation of Black Theology to its fullest and that, according to Kretzchmar, is what makes South African Black Theology distinct from Black Theology elsewhere in the world. Kretzchmar declares as follows:

It is thus the exploitative situation and the need for liberation that is the starting point for their theological reflection. ${ }^{55}$

Essentially the above-mentioned statements sum up the impact that Black Theology had on the mind and work of Allan Boesak. Boesak began his theological reflection within the framework of his understanding of the black situation in South Africa. Based on this understanding Boesak did

52 Boesak, Farewell to Innocence, 28.

53 Boesak, Farewell to Innocence, 28.

54 Kretzchmar, The Voice of Black Theology in South Africa, 73.

55 Kretzchmar, The Voice of Black Theology in South Africa, 75. 
his call to liberate the poor and oppressed. Boesak's exposure to Black Theology opens an entire new theological point of reference and handed him the "language" to engage within oppressive context of apartheid. That enabled Boesak to answer the call and challenge of Steve Biko. This "language" is still being used today and will be for a long time to come. Allan Boesak still helps us today in addressing the crucial of issues of global apartheid and oppression.

\section{Bibliography}

Boesak, A.A. 1976. Farewell to Innocence. A Social-Ethical Study on Black Theology and Black Power. Kampen: Uitgeversmaatschapij J.H. Kok.

Boesak, A.A. 2005. The Tenderness of Conscience. African Renaissance and the Spirituality of Politics. Stellenbosch: SUN Press.

Boesak, A.A. 2009. Running With Horses. Reflections of an accidental politician. Cape Town: Joho Publishers.

Kretzchmar, L. 1986. The Voice of Black Theology in South Africa. Johannesburg: Ravan Press.

Moore, B. (ed). 1973. Black Theology. The South African Voice. London: C. Hurst \& Company.

Scholtz, A. 1988. Die verhaal van Allan Boesak, Published doctoral thesis.

Sparks, A. 2003. The Mind of South Africa. The Story of the Rise and Fall of Apartheid. Jeppestown: Jonathan Ball Publishers (PTY) Ltd.

Stubbs, A. (red.). 2004. Steve Biko: I write what I like - A selection of his writings. Johannesburg: Picador Africa.

Wallis, T. 1989. "At the Apocalypse: The South African Church Claims its Hope. An interview with Allan Boesak". In: J. Wallis \& J. Holiday (reds.). Crucible of Fire. The Church confronts Apartheid. Maryknoll: Orbis Books. pp. $41-61$.

Welsh, D. 2009. The Rise and Fall of Apartheid. Johannesburg and Cape Town: Jonathan Ball Publishers. 